\title{
Central and Eastern Europe actual orthopaedics profile
}

\author{
Vane Antolič ${ }^{1}$ - Marko Bumbaširević ${ }^{2} \cdot$ Marko Pećina $^{3}$
}

Published online: 18 March 2021

(C) SICOT aisbl 2021

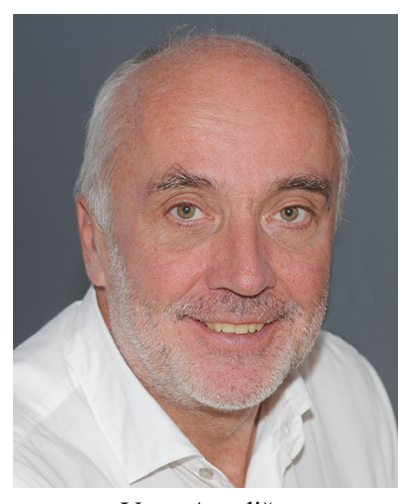

Vane Antolič

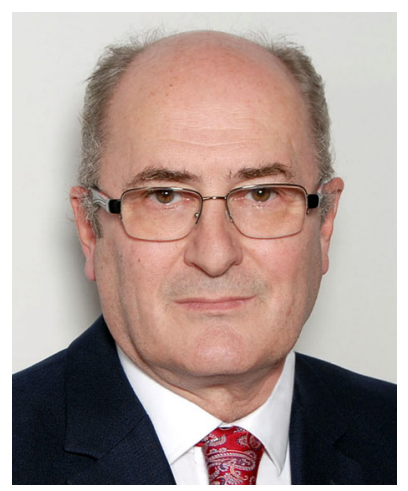

Marko Bumbaširević

Marko Pećina

marko.pecina@zg.t-com.hr

Vane Antolič

vane.antolic@guest.arnes.si

Marko Bumbaširević

marko.bumbasirevic@gmail.com

1 University Medical Centre Ljubljana, Zaloska 9 Street, 1000 Ljubljana, Slovenia

2 Clinic of Orthopedic Surgery and Traumatology, Clinical Centre of Serbia, 26 Visegradska Street, 11000 Belgrade, Serbia

3 University of Zagreb, School of Medicine, Salata 3, 10000 Zagreb, Croatia

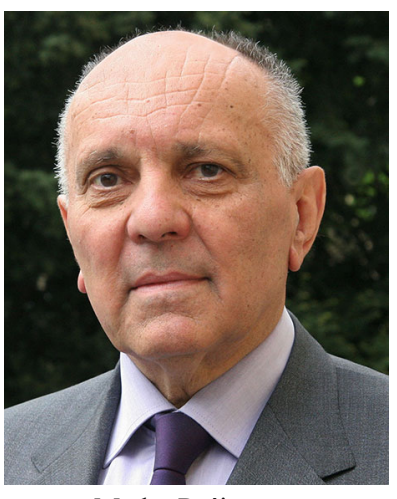

Marko Pećina

The Central and Eastern European Special Issue of International Orthopaedics Journal comes from countries, nations and peoples which long ago were living in mighty powerful empires and for centuries there was a clash between opposing interests and ideas due to various religions, cultures and traditions. The majority of people were suffering poverty and lack of personal liberty, countless died due to various diseases or were killed in numerous wars. Brave people started the liberation process very soon after the French Revolution, went through many socioeconomic and political developments, some gained independence as early as the nineteenth century, still others had to wait until the end of the First World War, and the last ones until the fall of the Iron Curtain and the Berlin Wall. People from this part of the world are now all living and enjoying personal and economic freedom. This Special Issue, with a representative insight of the state of the art in orthopaedics, is a proof that orthopaedic practice, professional career, and scientific work of the majority of the countries from the region are becoming internationally recognisable and comparable with the rest of the world as well. In this Special Issue, we have included papers from Austria, Bosnia, Croatia, Czech Republic, Greece, Poland, Romania, Serbia and Slovenia.

The great majority of articles in this Special Issue was "obtained" at the encouragement of editors, while some were included also from the contingent of articles 
regularly submitted and accepted for publication in International Orthopaedics.

When classifying papers, we adhered to the usual classification of papers in our journal. Therefore, in the General Orthopaedics section, the first introductory paper presented is the one on the influence of the state of emergency due to corona virus disease 2019 pandemic on orthopaedic fracture surgical treatment, which is only understandable considering the situation in which our profession finds itself [1] .It should be noted, of course, that a Special Issue of our journal has been published recently under the title COVID-19 and Orthopaedics [2] The next two papers in the general section of this issue are dedicated to the questions of prevention of infection either in terms of applying particular types of implants [3] and the possibilities of laboratory diagnostics of periprosthetic joint infection [4]. The review article by Trebse and Roskar presents the evaluation and interpretation of prosthetic joint infection diagnostic investigations [5].

Hip Joint issues are covered in the ten following papers, among which we draw your attention to a double-blind randomized study about the effect of pre-operative high doses of methylprednisolone on pain management and convalescence after total hip replacement in elderly [6]. Also, the article on the always current issue in the field of hip replacement, the effectiveness of different doses and routes of administration of tranexamic acid for total hip replacement [7], merits attention. Patient specific template in a novel concept of cam-type femoroacetabular impingement treatment and in Bernese peri-acetabular osteotomy are presented by the same group of authors from Slovenia $[8,9]$. The problem of leg-length discrepancy after total hip arthroplasty is the subject of the article by Mavčić and Antolič [10]. Stražar presents the current status and personal system of computer assistance in hip preservation surgery [11]. Cemented stems in healthy elderly patients result in higher hypoxia despite a paradoxical lower femoral increase of intramedullary pressure according to investigation of S. Ukaj and the international group of authors [12].

In the section dedicated to Knee Pathology the prospective study of autologous chondrocytes versus filtered bone marrow mesenchymal stem/stromal cells for knee cartilage repair [13] is of great value. Czech authors present their own experiences in the prospective long-term assessment of meniscus transplantation [14], while our Croatian colleagues present the results after polyurethane meniscal scaffold implantation following partial menicectomy [15]. Tibial tuberosity-tibial intercondylar midpoint distance measured on computed tomography scanner could be clinically more relevant than current measurement systems according to investigation of group of authors from Croatia [16].

The paper titled Early neonatal universal ultrasound screening for developmental dysplasia of the hip: a single institution observational study is a very valuable contribution to the problem of resolving developmental dysplasia of the hip [17], and the paper Reduction of spondylolisthesis and sagittal balance correction by anterior lumbar interbody fusion (ALIF) deserves special notice due to biomechanical explanations accompanied by appropriate drawings [18].

Among the papers devoted to the problem of upper limb attention must be paid to the article of Bartoniček et al. titled „Fractures of the coracoid process - pathoanatomy and classification: based on thirty nine cases with three dimensional computerised tomography reconstructions [19]. Medančić et al. consider arthroscopic removal of arch-shaped rotator cuff calcifying tendinitis without rotator cuff repair and acromioplasty is an excellent treatment regarding pain relief and function [20]. Matić et al. compared pedicled vascularized bone grafts with xenografts in the treatment of scaphoid nonunion [21].

The articles about the clinical outcomes after arthroscopically assisted talus fracture fixation [22] and about the treatment of hallux rigidus by a novel bi-phasic aragonitebased implant: results of a two year multi-centre clinical trial [23] are included in Foot and Ankle section of this issue.

Two articles titled: Importance of shear-wave elastography in prediction of Achilles tendon rupture [24] and Patientreported joint status and quality of life in sports-related ankle disorders and osteoarthritis [25] are included in the Foot and Ankle section, although they can be a part of the Sports Medicine section.

Trauma is represented in this issue by three articles, one article about the fractures of the acetabulum [26], one article about T-condylar humerus fracture in children [27] and the last about lateral tibial plateau fractures - functional outcomes and complications after open reduction and internal fixation [28].

In the Tumour section, a group of authors presents the Implementation of the three-dimensional printing technology in treatment of bone tumours: a case series [29].

Particularly worth mentioning are two articles in our Basic Research section. In the first of them titled: „Synthetic ceramic macroporous blocks as a scaffold in ectopic bone formation induced by recombinant human bone morphogenetic protein 6 within autologous blood coagulum "[30] , provides the latest discoveries made by professor Vukičević's scientific team - the so-called Zagreb BMP Group, and the second article , Macrophages' contribution to ectopic osteogenesis in combination with blood clot and bone substitute: possibility for application in bone regeneration strategies "is submitted by professor Živković's scientific team from Niš, Serbia [31].

Orthopaedic Heritage article in this Special Issue is of especially great interest because we can see more than 100 years old photos about the rehabilitations of disabled war veterans in Croatia during the Great War. [32]. 
We are aware that we have not fully accomplished our task contained in the title of our EDITORIAL, and that we have definitely not shown the complete profile of orthopaedics and traumatology in the countries of Central and Eastern Europe, but we believe that we have brought closer to our readers the current status of orthopaedics in this small corner of the orthopaedic globe (universe, cosmos).

\section{References}

1. Mitkovic MM, Bumbaširevic M, Milenkovic S, Dj G, Bumbasirevic V, Mitkovic MB (2020) Influence of corona virus disease 2019 pandemic state of emergency in orthopaedic fracture surgical treatment. Int Orthop. https://doi.org/10.1007/s00264020-04750-3

2. Khanduja V, Scarlat MM (2020) Reaching a new 'normal' after COVID pandemic and orthopaedic implications. Int Orthop 44: 1449-1451. https://doi.org/10.1007/s00264-020-04725-4

3. Tsikopoulos K, Sidiropoulos K, Kitridis D, Hassan A, Drago L, Mavrogenis A, McBride D (2020) Is coating of implants effective at preventing Staphylococcus aureus infections? A meta-analysis of animal model studies. Int Orthop. https://doi.org/10.1007/s00264020-04660-4

4. Sigmund IK, Holinka J, Staats K, Sevelda F, Lass R, Kubista B, Giurea A, Windhager R (2020) Inferior performance of established and novel serum inflammatory markers in diagnosing periprosthetic joint infection. Int Orthop. https://doi.org/10.1007/s00264-02004889-z

5. Trebse R, Roskar S (2021) Evaluation and interpretation of prosthetic joint infection diagnostic investigations. Int Orthop. https:// doi.org/10.1007/s00264-021-04958-x

6. Gadek A, Liszka H, Zając M (2020) The effect of pre-operative high doses of methylprednisolone on pain management and convalescence after total hip replacement in elderly: a double-blind randomized study. Int Orthop. https://doi.org/10.1007/s00264-02004802-8

7. Palija S, Bijeljac S, Manojlovic S, Jovicic Z, Jovanovic M, Cvijic P, Dragicevic-Cvjetković D (2020) Effectiveness of different doses and routes of administration of tranexamic acid for total hip replacement. Int Orthop. https://doi.org/10.1007/s00264-020-04585-y

8. Mihalič R, Brumat P, Trebše R (2020) A novel concept of cam-type femoroacetabular impingement treatment with patient-specific template guided osteochondral deformity ablation. Int Orthop. https:// doi.org/10.1007/s00264-020-04887-1

9. Mihalič R, Brumat P, Trebše R (2020) Bernese peri-acetabular osteotomy performed with navigation and patient-specific templates is a reproducible and safe procedure. Int Orthop. https://doi. org/10.1007/s00264-020-04897-Z

10. Mavčič B, Antolič V (2020) Cementless femoral stem fixation and leg-length discrepancy after total hip arthroplasty in different proximal femoral morphological types. Int Orthop. https://doi.org/10. 1007/s00264-020-04671-1

11. Stražar K (2020) Computer assistance in hip preservation surgerycurrent status and introduction of our system. Int Orthop. https:// doi.org/10.1007/s00264-020-04788-3

12. Ukaj S, Veslko M, Krasniqi S, Podvorica V, Ukaj F, Ahmeti A, Hernigou P, Cimerman M (2021) Cemented stems in healthy elderly patients result in higher hypoxia despite a paradoxical lower femoral increase of intramedullary pressure. Int Orthop. https:// doi.org/10.1007/s00264-021-04955-0
13. Martinčič D, Leban J, Filardo G, Busacca M, Barlič A, Veber M, Drobnič M (2020) Autologous chondrocytes versus filtered bone marrow mesenchymal stem/stromal cells for knee cartilage repaira prospective study. Int Orthop. https://doi.org/10.1007/s00264020-04727-2

14. Paša L, Kužma J, Herufek R, Prokeš J, Jarkovsky J, Havlas V (2020) Meniscus transplantation - prospective assessment of clinical results in two, five and ten year follow-up. Int Orthop. https:// doi.org/10.1007/s00264-020-04638-2

15. Hašpl M, Trsek D, Lovric D, Strahonja B, Matokovic D (2020) Functional and magnetic resonance imaging outcome after polyurethane meniscal scaffold implantation following partial meniscectomy. Int Orthop. https://doi.org/10.1007/s00264-02004844-y

16. Nizić D, Šimunović M, Pavliša G, Jelić M (2020) Tibial tuberositytibial intercondylar midpoint distance measured on computed tomography scanner is not biased during knee rotation and could be clinically more relevant than current measurement systems. Int Orthop. https://doi.org/10.1007/s00264-020-04820-6

17. Treiber M, Korpar B, Sirše M, Merc M (2020) Early neonatal universal ultrasound screening for developmental dysplasia of the hip: a single institution observational study. Int Orthop. https://doi.org/ 10.1007/s00264-020-04915-0

18. Caprariu R, Popa I, Opra M, Niculescu M, Poenaru D, Birsasteanu F (2020) Reduction of spondylolisthesis and sagittal balance correction by anterior lumbar interbody fusion (ALIF). Int Orthop. https://doi.org/10.1007/s00264-020-04900-7

19. Bartoniček J, Tuček M, Strnad T, Nanka O (2020) Fractures of the coracoid process - pathoanatomy and classification: based on thirty nine cases with three dimensional computerised tomography reconstructions. Int Orthop. https://doi.org/10.1007/s00264-020-04634-6

20. Medancic N, Spanic M, Budimir Marinic T, Klobucar H, Cicak N (2020) Arthroscopic removal of arch-shaped rotator cuff calcifying tendinitis without rotator cuff repair and acromioplasty is an excellent treatment regarding pain relief and function. Int Orthop. https:// doi.org/10.1007/s00264-020-04930-1

21. Matić S, Vučković Č, Lešić A, Glišović Jovanović I, Polojac D, Dučić S, Bumbaširević M (2020) Pedicled vascularized bone grafts compared with xenografts in the treatment of scaphoid nonunion. Int Orthop. https://doi.org/10.1007/s00264-020-04828-y

22. Bardas CA, Benea HRC, Apostu D, Olteon-Dan D, Tomoaia G, Bauer T (2020) Clinical outcomes after arthroscopically assisted talus fracture fixation. Int Orthop. https://doi.org/10.1007/s00264020-04859-5

23. Drobnič M, Vannin F, Kon E, Dulić O, Kecojević V, Andor B, Altschuler N, Robinson D (2020) Treatment of hallux rigidus by a novel bi-phasic aragonite-based implant: results of a two year multi-centre clinical trial. Int Orthop. https://doi.org/10.1007/ s00264-020-04872-8

24. Ivanac G, Lemac D, Kosovic V, Bojanic K, Cengic T, Dumic-Cule I, Pecina M, Brkljacic B (2020) Importance of shear-wave elastography in prediction of Achilles tendon rupture. Int Orthop. https://doi.org/10.1007/s00264-020-04670-2

25. Kolar M, Brulc U, Stražar K, Drobnič M (2020) Patient-reported joint status and quality of life in sports-related ankle disorders and osteoarthritis. Int Orthop. https://doi.org/10.1007/s00264-02004747-y

26. Cimerman M, Kristan A, Jug M, Tomaževič M (2020) Fractures of the acetabulum: from yesterday to tomorrow. Int Orthop. https:// doi.org/10.1007/s00264-020-04806-4

27. Dučić S, Stojanović B, Lazović M, Bukva B, Radlovica V, Bumbaširević V, Djordjevic ML (2020) T-condylar humerus fracture in children: treatment options and outcomes. Int Orthop. https://doi.org/10.1007/s00264-020-04827-z

28. Milenkovic S, Mitkovic M, Mitkovic M, Stoiljkovic P, Stojanovic M (2020) Lateral tibial plateau fractures - functional outcomes and 
complications after open reduction and internal fixation. https://doi. org/10.1007/s00264-020-04763-y

29. Šimić Jovičić M, Vuletić F, Ribičić T, Šimunić S, Petrović T, Kolundžić R (2020) Implementation of the three-dimensional printing technology in treatment of bone tumours: a case series. Int Orthop. https://doi.org/10.1007/s00264-020-04788-3

30. Stokovic N, Ivanjko N, Milesevic M, Matic Jelic I, Bakic K, Rumenovic V, Oppermann H, Shimp L, Kuber Sampath T, Pecina M, Vukicevic S (2020) Synthetic ceramic macroporous blocks as a scaffold in ectopic bone formation induced by recombinant human bone morphogenetic protein 6 within autologous blood coagulum. Int Orthop. https://doi.org/10.1007/s00264-02004847-9
31. Živković JM, Stojanović ST, Vukelić-Nikolić MĐ, Radenković MB, Najdanović JG, Ćirić M, Najman SJ (2020) Macrophages' contribution to ectopic osteogenesis in combination with blood clot and bone substitute: possibility for application in bone regeneration strategies. Int Orthop. https://doi.org/10.1007/s00264-020-04826-0

32. Fatović-Ferenčić S, Kuhar M (2020) 'Images from our orthopaedic hospital': photography in the rehabilitation of disabled war veterans in Croatia during the first world war. Int Orthop. https://doi.org/10. 1007/s00264-020-04837-x

Publisher's note Springer Nature remains neutral with regard to jurisdictional claims in published maps and institutional affiliations. 